\title{
Penguasaan Keterampilan Dasar Mengajar Mahasiswa Program Studi Pendidikan Bahasa Arab di Universitas Negeri Jakarta
}

\author{
Fatwa Arifah*, Chakam Failasuf, Erika Novianisa \\ Universitas Negeri Jakarta, Indonesia
}

\section{Mastery of Basic Teaching Skills for the Students of the Arabic Language Education Study Program at Universitas Negeri Jakarta}

E-Mail Address

fatwa.arifah@unj.ac.id

${ }^{*}$ Corresponding Author

\begin{abstract}
This study aims to get a clear description of the basic teaching skills for students of the Arabic Language Education Study Program, Faculty of Languages and Arts, Universitas Negeri Jakarta. The research method used in this study is a mixed-method which is a combination of quantitative research methods and qualitative research methods. The research location is in one of the Universitas Negeri Jakarta classrooms and the research subjects consisted of 45 students class of 2016 in the Arabic Language Education Study Program who took Micro Teaching course. Data collection techniques using observation and documentation instruments. The percentage of the highest to lowest average scores in basic teaching skills mastered by students on the exam, small groups and individuals, with a value of $89.42 \%$ in the very good category, and skills of reinforcement obtained an average value of $85.00 \%$ with enough category. With this research, researchers gain an understanding of basic teaching skills as well as data related to teaching skills in the Arabic Language Education Study Program, Universitas Negeri Jakarta. This research also can be used as a guideline for other researchers regarding basic teaching skills.
\end{abstract}

\section{Keywords}

Basic teaching skills; teacher skills;

Arabic language learning

\section{Pendahuluan}

Pendidikan merupakan salah satu pilar dan modal utama dalam mengantisipasi dan menyongsong masa depan. Pendidikan diorientasikan untuk mengembangkan sumber daya manusia guna dapat berperan di masa yang akan datang dan diarahkan kepada kebutuhan manusia. Salah satu komponen pendidikan yang perlu dipersiapkan adalah tenaga pendidik atau guru. Universitas Negeri Jakarta sebagai salah satu lembaga pendidikan yang mempersiapkan tenaga guru yang profesional perlu melakukan inovasi dalam pembelajarannya.

Pertama kali yang mesti dilakukan adalah dengan menelaah lebih lanjut tentang kompetensi apa saja yang harus dimiliki seorang guru. Menurut Agus F. Tamyong yang dikutip oleh Uzer Usman (2005), yang dimaksud dengan guru yang profesional adalah "orang yang terdidik dan terlatih 
dengan baik, sehingga memiliki pengalaman yang kaya di bidangnya”. Lebih lanjut, juga dijelaskan dalam UU RI No. 14 Tahun 2005 pasal 20 tentang Guru dan Dosen, bahwa dalam menjalankan tugasnya guru berkewajiban untuk (1) merencanakan pembelajaran, yang melaksanakan proses pembelajaran yang bermutu, serta menilai dan mengevaluasi hasil pembelajaran; (2) meningkatkan pengembangan kualifikasi akademik dan kompetensi secara berkelanjutan sejalan dengan perkembangan ilmu pengetahuan, teknologi, dan seni; (3) bertindak objektif dan tidak diskriminatif atas dasar perkembangan jenis kelamin, agama, suku, ras dan kondisi fisik tertentu, atau latar belakang keluarga, dan status sosial ekonomi peserta didik dalam pembelajaran; (4) menjunjung tinggi peraturan perundang-undangan hukum, dan kode etik guru, serta nilai-nilai agama dan etika; (5) memelihara dan memupuk persatuan dan kesatuan bangsa.

Pendidikan Akutansi, Pendidikan Biologi, dan Pendidikan Kimia, misalnya, adalah beberapa contoh program studi yang membutuhkan pemahaman yang mendalam dalam memahami setiap materi yang dipelajari di dalamnya. Oleh karena itu, jika penyampaian materi pelajaran dilakukan hanya dengan menggunakan metode ceramah, maka peserta didik akan sulit memahaminya. Terdapat beberapa penelitian yang dapat dijadikan studi pendahuluan terkait dengan keterampilan dasar mengajar, di antaranya penelitian yang dilakukan oleh Siswato (2010) melalui penelitiannya terhadap mahasiswa Program Studi Pendidikan Akuntansi, Universitas Negeri Yogyakarta (UNY) angkatan 2007 yang melaksanakan Praktik Pengalaman Lapangan (PPL). Hasilnya membuktikan bahwa keterampilan mengajar mahasiswa Pendidikan Akuntansi sudah mendapatkan kategori tertinggi dalam penilaian, yaitu "Terampil”. Keterampilan dengan penguasaan tertinggi didapatkan pada keterampilan membuka dan menutup pelajaran sebagai keterampilan paling dikuasai oleh mahasiswa Pendidikan Akutansi angkatan 2007 yang melaksanakan PPL.

Penelitian lainnya terhadap mahasiswa yang melaksanakan PPL juga dilakukan oleh Wijarini dan Silfia Ilmia (2017). Penelitian dilakukan terhadap mahasiswa Program Studi Pendidikan Biologi, Universitas Muhammadiyah Malang (UMM) angkatan 2013. Dari penelitian tersebut didapatkan hasil bahwa mahasiswa Pendidikan Biologi yang melaksanakan PPL sudah menguasai $83 \%$ dari 8 keterampilan dasar mengajar dengan kategori "Sangat Baik". Dewi Purwanti (2017), di sisi lain, melakukan penelitian tentang penguasaan 8 keterampilan dasar mengajar yang dimiliki para mahasiswa Program Studi Pendidikan Kimia angkatan 2013 di Universitas Islam Negeri (UIN) Walisongo Semarang yang melaksanakan mata kuliah Micro Teaching. Dari penelitian tersebut didapatkan hasil bahwa mahasiswa masih kurang menguasai 8 keterampilan dasar mengajar saat mata kuliah Micro Teaching berlangsung. Keterampilan dengan penguasaan tertinggi didapatkan pada keterampilan menggunakan variasi dengan presentase 31\%, dan keterampilan dengan penguasaan terendah didapatkan pada keterampilan mengelola kelas dengan presentase 5\%. Penelitian tersebut juga merekomendasikan agar Program Studi Pendidikan Kimia memberikan pembekalan yang terkait dengan 8 keterampilan dasar mengajar bagi seluruh mahasiswa. Selain itu, juga menyarankan kepada seluruh mahasiswa untuk meningkatkan kemampuannya dalam mengaplikasikan 8 keterampilan dasar mengajar. Salah satu yang utama adalah dengan menekankan keterampilan bertanya, karena keterampilan ini sangat memberikan pengaruh besar terhadap pemahaman siswa.

Dari bacaan terhadap studi pendahuluan tersebut, peneliti melihat masih minimnya penelitian mengenai Micro Teaching bahasa Arab. Oleh karena itu, tulisan ini akan menganalisa penguasaan keterampilan dasar mengajar mahasiswa Program Studi Pendidikan Bahasa Arab (Prodi PBA) di 
Universitas Negeri Jakarta (UNJ) yang mengikuti mata kuliah Pembinaan Kompetensi Mengajar (PKM).

\section{Landasan Teori}

\section{A. Keterampilan Dasar Mengajar}

Turney (1973) mengemukakan 8 keterampilan dasar mengajar, yaitu:

1. Keterampilan bertanya

Bertanya adalah bahasa verbal untuk meminta respon siswa baik berupa pengetahuan, pendapat, ataupun sekedar mengembalikan konsentrasi siswa yang terdestruksi oleh berbagai kondisi selama kegiatan belajar mengajar (KBM) berlangsung. Dalam proses belajar mengajar, bertanya memainkan peranan penting. Bertanya dapat menjadi stimulus yang efektif untuk mendorong kemampuan berpikir siswa. Oleh karena itu, untuk meningkatkan partisipasi siswa dalam proses belajar mengajar, guru perlu menunjukkan sikap yang baik ketika mengajukan pertanyaan maupun menerima jawaban siswa. Guru hendaknya menghindari kebiasaan seperti menjawab pertanyaan sendiri, mengulang jawaban siswa, mengulang pertanyaan sendiri, mengajukan pertanyaan dengan jawaban serentak, menentukan siswa yang harus menjawab sebelum bertanya, dan mengajukan pertanyaan ganda. Kegiatan bertanya dalam kegiatan belajar mengajar ini akan lebih efektif bila pertanyaan yang diajukan cukup berbobot, mudah dimengerti atau relevan dengan topik yang dibicarakan. Sementara itu, tujuan guru mengajukan pertanyaan antara lain untuk (a) menimbulkan rasa ingin tahu; (b) merangsang fungsi berpikir; (c) mengembangkan keterampilan berpikir; (d) Memfokuskan perhatian siswa; (e) mendiagnosis kesulitan belajar siswa; dan (f) mengomunikasikan harapan yang diinginkan oleh guru dari siswanya.

\section{Keterampilan memberikan penguatan}

Penguatan (reinforcement) adalah segala bentuk respons, baik bersifat verbal maupun nonverbal, yang merupakan bagian dari modifikasi tingkah laku guru terhadap tingkah laku siswa. Penguatan ini bertujuan untuk memberikan informasi atau umpan balik (feedback) bagi si penerima (siswa) atas perbuatannya sebagai suatu dorongan atau koreksi. Penguatan juga merupakan respons terhadap tingkah laku yang dapat meningkatkan kemungkinan berulangnya kembali tingkah laku tersebut.

Teknik pemberian penguatan dalam kegiatan belajar mengajar yang bersifat verbal dapat dinyatakan melalui pujian, penghargaan, ataupun persetujuan. Sementara itu, penguatan nonverbal dapat dinyatakan melalui gestur, mimik muka (ekspresi), penguatan dengan cara mendekati, penguatan dengan sentuhan (contact), penguatan dengan kegiatan yang menyenangkan, dan lain sebagainya. Di dalam pengelolaan kelas, dikenal dengan istilah penguatan positif dan penguatan negatif. Penguatan positif bertujuan untuk mempertahankan dan memelihara perilaku positif, sedangkan penguatan negatif merupakan penguatan perilaku dengan cara menghentikan atau menghapus rangsangan yang tidak menyenangkan. Manfaat penguatan bagi siswa adalah untuk meningkatkan perhatian (fokus) siswa dalam belajar, membangkitkan dan memelihara perilaku, menumbuhkan rasa percaya diri, dan lain sebagainya. 


\section{Keterampilan mengadakan variasi}

Variasi dalam kegiatan belajar mengajar dimaksudkan sebagai perubahan dalam proses interaksi belajar mengajar. Dalam konteks ini, variasi merujuk pada tindakan dan perbuatan guru, baik yang disengaja ataupun secara spontan, yang dimaksudkan untuk meningkatkan dan mengikat perhatian siswa selama pembelajaran berlangsung. Tujuan utama dari variasi dalam kegiatan pembelajaran ini adalah untuk mengurangi rasa bosan (boring) yang membuat siswa tidak lagi fokus pada proses kegiatan belajar mengajar yang sedang berlangsung. Untuk itu, guru perlu melakukan berbagai variasi sehingga perhatian siswa tetap terpusat pada pelajaran. Beberapa variasi yang dapat dilakukan guru selama proses kegiatan belajar mengajar, di antaranya adalah: penggunaan variasi suara (teacher voice), pemusatan perhatian siswa (focusing), kesenyapan/kebisuan guru (teacher silence), kontak pandang dan gerak (eye contact and movement), gestur/gerak tubuh, ekspresi wajah guru, pergantian posisi guru dalam kelas dan gerak guru (teacher movement), variasi penggunaan media dan alat pengajaran, dan lain sebagainya.

\section{Keterampilan membuka dan menutup pelajaran}

Keterampilan membuka pelajaran adalah usaha guru untuk mengondisikan mental peserta didik agar siap dalam menerima pelajaran. Dalam membuka pelajaran, peserta didik harus mengetahui tujuan yang akan dicapai dan langkah-langkah yang akan ditempuh. Sementara itu, keterampilan menutup pelajaran adalah keterampilan guru dalam mengakhiri kegitan inti pelajaran. Dalam menutup pelajaran, guru dapat menyimpulkan materi pelajaran, mengetahui tingkat pencapaian peserta didik dan tingkat keberhasilan guna dalam proses belajar mengajar. Tujuan dari membuka dan menutup pelajaran ini adalah untuk (a) menimbulkan minat dan perhatian peserta didik terhadap pelajaran yang akan dibicarakan; (b) menyiapkan mental para peserta didik agar siap memasuki persoalan yang akan dibicarakan; (c) memungkinkan peserta didik mengetahui tingkat keberhasailan dalam pelajaran; dan (d) agar peserta didik mengetahui batas-batas tugasnya yang akan dikerjakan.

\section{Keterampilan menjelaskan}

Keterampilan menjelasakan adalah suatu keterampilan menyajikan bahan belajar yang diorganisasikan secara sistematis sebagai suatu kesatuan yang berarti sehingga mudah dipahami para peserta didik. Adapun prinsip-prinsip menjelaskan, yaitu: (a) penjelasan harus disesuaikan dengan kemampuan dan karakteristik peserta didik; (b) penjelasan harus diselingi tanya jawab; (c) materi penjelasan harus bermanfaat dan bermakna bagi peserta didik; dan (d) dapat menjelaskan harus disertai dengan contoh-contoh yang konkret dan dihubungkan dengan kehidupan.

\section{Keterampilan membimbing diskusi kelompok kecil}

Diskusi kelompok merupakan salah satu variasi kegiatan pembelajaran yang dapat digunakan dalam proses kegiatan belajar mengajar. Dalam diskusi kelompok, siswa dalam tiap kelompok kecil dapat bertukar informasi dan pengalaman, melakukan pengambilan keputusan bersama, serta belajar melakukan pemecahan masalah (problem solving). Diskusi kelompok merupakan strategi yang memungkinkan siswa menguasai suatu konsep atau memecahkan suatu masalah melalui satu proses yang memberi kesempatan untuk berpikir, berinteraksi sosial, serta berlatih bersikap positif. Dengan 
demikian, diskusi kelompok dapat meningkatkan kreativitas siswa, serta membina kemampuan berkomunikasi termasuk di dalamnya keterampilan berbahasa.

\section{Keterampilan mengelola kelas}

Suasana belajar mengajar yang baik sangat menunjang efektivitas pencapaian tujuan pembelajaran. Seorang guru harus mampu menjadi manager yang baik dalam sebuah proses kegiatan belajar mengajar. Hal ini berarti bahwa guru harus terampil menciptakan suasana belajar yang kondusif, serta mampu menjaga dan mengembalikan kondisi belajar yang optimal. Selain itu, juga dapat meminimalisir gangguan yang mungkin terjadi selama proses kegiatan belajar mengajar, sehingga siswa dapat fokus pada kegiatan belajar mengajar yang berlangsung. Dalam melaksanakan keterampilan mengelola kelas, guru perlu memperhatikan komponen keterampilan yang berhubungan dengan penciptaan dan pemeliharaan kondisi belajar yang optimal (bersifat preventif), seperti kemampuan guru dalam mengambil inisiatif dan mengendalikan pelajaran Di sisi lain, guru juga perlu memperhatikan keterampilan yang bersifat represif, yaitu keterampilan yang berkaitan dengan respons guru terhadap gangguan siswa yang berkelanjutan dengan maksud agar guru dapat mengadakan tindakan remedial untuk mengembalikan kondisi belajar yang optimal.

\section{Keterampilan mengajar kelompok kecil dan perorangan}

Jumlah siswa dalam bentuk pengajaran seperti ini berkisar 3 sampai dengan 8 orang untuk setiap kelompok kecil, dan 1 orang untuk perseorangan. Terbatasnya jumlah siswa dalam pengajaran bentuk ini memungkinkan guru memberikan perhatian secara optimal terhadap setiap siswa. Hubungan antara guru dan siswa pun menjadi lebih akrab, demikian pula hubungan antar siswa. Dengan demikian, dapat dikatakan bahwa format mengajar seperti ini ditandai oleh adanya hubungan interpersonal yang lebih akrab dan sehat antara guru dengan siswa, adanya kesempatan bagi siswa untuk belajar sesuai dengan kemampuan, minat, cara, dan kecepatannya, adanya bantuan dari guru, adanya keterlibatan siswa dalam merancang kegiatan belajarnya, serta adanya kesempatan bagi guru untuk memainkan berbagai peran dalam kegiatan pembelajaran. Setiap guru dapat menciptakan format pengorganisasian siswa untuk kegiatan pembelajaran kelompok kecil dan perorangan sesuai dengan tujuan, topik (materi), kebutuhan siswa, serta waktu dan fasilitas yang tersedia. Komponen-komponen dan prinsip-prinsip keterampilan ini adalah: ketrampilan mengadakan pendekatan secara pribadi, keterampilan mengorganisasi, keterampilan membimbing dan memudahkan belajar, keterampilan merencanakan dan melaksanakan kegiatan belajar mengajar, dan keterampilan merancang dan melaksanakan kegiatan pembelajaran.

\section{B. Indikator Penilaian dalam Keterampilan Dasar Mengajar}

Helmiati (2013) memaparkan indikator penilaian keterampilan dasar mengajar sebagai berikut:

\section{Membuka dan menutup pelajaran}

Dalam membuka pelajaran, setidaknya ada beberapa yang dapat diperhatikan, yaitu memfokuskan perhatian dan membangkitkan minat siswa, menimbulkan motivasi, memberi acuan, dan mengaitkan pelajaran yang telah dipelajari dengan topik baru. Dengan memfokuskan perhatian dan 
membangkitkan minat siswa, paling tidak ada beberapa hal yang bisa dilakukan, yaitu mengaitkan materi dengan berita terkini, menyampaikan cerita, menggunakan alat peraga atau media, memvariasikan gaya mengajar, menyinggung tentang tugas-tugas yang dilakukan siswa, dan mengandaikan persoalan. Dalam menimbulkan motivasi, yang dapat dilakukan adalah dengan memberikan kehangatan dan menunjukkan sikap antusias, menimbulkan rasa ingin tahu, dan mengemukakan ide yang bertentangan. Dalam memberikan acuan, bisa dilakukan dengan memberikan tujuan pembelajaran, menyampaikan garis besar pembelajaran, dan menjelaskan langkah-langkah kegiatan pembelajaran. Sementara itu, dalam mengaitkan pelajaran yang telah dipelajari dengan topik baru, bisa melakukan hal-hal seperti mengajukan pertanyaan tentang materi sebelumnya, dan membandingkan pengetahuan yang lama dan yang akan disajikan.

Untuk menutup pelajaran, yang dapat dilakukan adalah dengan meninjau kembali (reviewing) dan melakukan evaluasi. Dalam me-review, bisa dimulai dengan merangkum inti pokok pelajaran, kemudian mengonsolidasikan perhatian siswa pada pokok pembahasan. Sementara itu, dalam mengevaluasi, dapat dilakukan dengan mendemonstrasikan penampilan, mengaplikasikan ide baru, mengekspresikan pendapat, dan memberikan soal-soal.

\section{Keterampilan menjelaskan pelajaran}

Keterampilan yang harus dilakukan dalam menjelaskan pelajaran antara lain dengan menggunakan bahasa secara baik dan benar, menggunakan bahasa yang jelas, suara terdengar ke seluruh penjuru kelas, volume suara bervariasi, menghindari kata-kata yang tidak perlu, menghindari penggunakan kata "mungkin" yang salah pemakaian, dan menjelaskan pengertian istilah asing dan baru secara tuntas. Selain itu, penting juga untuk meneliti pemahaman siswa terhadap penjelasan guru, memberi contoh nyata uraian materi sesuai pengalaman siswa, memberikan penjelasan secara deduktif/induktif dan membuat generalisasi, menggunakan multimedia bila diperlukan, menggunakan bagan untuk menjelaskan hubungan dan hirarki, menerima umpan balik dari siswa, memberikan kesempatan pada siswa untuk memberikan contoh sesuai dengan pengalamannya masing-masing, dan terakhir, memberikan penekanan pada hal penting.

\section{Keterampilan bertanya}

Keterampilan bertanya terdiri dari keterampilan bertanya dasar dan keterampilan bertanya lanjut. Dalam keterampilan bertanya dasar, ada beberapa hal yang perlu diperhatikan, yaitu: (a) mengungkapkan pertanyaan dalam bahasa yang jelas dan singkat; (b) memiliki tujuan yang jelas, dan tidak menimbulkan tafsiran ganda; (c) memusatkan pertanyaan ke arah jawaban yang diminta; (d) mendorong siswa untuk berfikir kritis, jawaban yang diharapkan bukan hanya sekedar "ya" atau "tidak"; (e) mengajukan pertanyaan secara klasikal terlebih dahulu, kemudian secara individual dengan cara menyebut nama atau menunjuk siswa; (f) mengajukan pertanyaan secara acak dan menggilirkan siswa secara rata; (g) memberikan waktu untuk siswa berfikir; (h) memberikan tuntunan kepada siswa agar dapat menemukan jawaban yang benar dengan cara mengungkapkan kembali pertanyaan dengan bahasa yang lebih sederhana bila diperlukan; (i) menciptakan iklim hubungan yang intim antara guru dengan siswa, dan siswa dengan siswa; (j) menghargai siswa sebagai insan pribadi dan insan sosial yang memiliki hakikat dan harga diri. 
Sementara itu, yang harus diperhatikan dalam keterampilan bertanya lanjut, yaitu: (a) mengajukan pertanyaan yang mengubah tingkat kognititf siswa dalam menjawab suatu pertanyaan dari tingkat yang rendah ke yang lebih tinggi; (b) pengaturan urutan pertanyaan secara tepat, dari tingkat pemahaman ke penerapan, analisis, sintaksis dan evaluasi; dan (c) menggunakan pertanyaan pelacak dengan cara meminta klarifikasi, alasan, kesepakatan dan pandangan, ketepatan jawaban, contoh, jawaban yang relevan atau jawaban yang kompleks.

\section{Keterampilan mengadakan variasi}

Keterampilan mengadakan variasi bisa dilakukan dengan variasi dalam gaya belajar; variasi dalam penggunaan media dan alat pembelajaran, baik yang bersifat audio, visual, dan motorik, maupun dengan variasi pola interaksi dan aktivitas siswa. Ada beberapa hal yang harus diperhatikan dalam keterampilan mengadakan variasi, yaitu: (a) ada variasi dalam nada dan volume suara serta kecepatan bicara; (b) variasi dalam ekspresi wajah gerakan kepala/badan untuk memperjelas penyajian; (c) menarik perhatian siswa dengan kesenyapan atau kebisuan guru (teacher silence); (d) mengadakan kontak pandang dengan siswa perubahan gerak (eye contact and movement); (e) pemusatan perhatian siswa (focusing); dan (f) pergantian posisi guru di dalam kelas (teacher movement).

\section{Keterampilan memberikan penguatan}

Dalam keterampilan memberikan penguatan, terdapat beberapa hal yang dapat diperhatikan, yaitu (a) guru memberikan penguatan secara verbal berupa kalimat menghargai/kata-kata "ya”, "bagus", "tepat", dan lainya; (b) guru memberikan penguatan secara gestur (gerak), dalam bentuk mimik, senyum, kerlingan mata, tepuk tangan, anggukan kepala, dan menaikkan jempol; (c) guru memberikan pnguatan dengan mendekati siswa atau duduk dalam kelompok diskusinya untuk memberikan perhatian terhadap aktivitasnya; (d) guru memberikan penguatan dengan sentuhan, seperti menepuk-nepuk pundak siswa, menjabat tangan atau mengangkat tangan siswa; (e) guru memberikan penguatan dengan memberikan hadiah/tanda atau memberi komentar pada tugas tertulis; dan (f) guru memberikan pekerjaan yang menyenangkan, seperti siswa untuk membantu temannya atau memimpin suatu kegiatan.

\section{Keterampilan mengelola kelas}

Dalam keterampilan mengelola kelas bisa dilakukan dengan upaya (a) penciptaan dan pemeliharaan kondisi belajar yang optimal. Ini bisa dilakukan dengan memusatkan perhatian siswa yang dilakukan dengan cara memperhatikan sikap dan tempat duduk siswa, dan memulai pelajaran setelah nampak siswa siap belajar. Cara lainnya adalah dengan menunjukkan sikap tanggap yang dilakukan dengan memandang secara seksama, gerak mendekati, mengajukan pertanyaan, dan memberikan reaksi terhadap gangguan dan ketakacuhan siswa. Selain itu, membagi perhatian baik secara verbal maupun visual, memberikan petunjuk yang jelas, memberi teguran secara bijaksana, dan memberi penguatan bila diperlukan, juga dapat dilakukan; (b) Pengendalian kondisi belajar yang optimal. Upaya ini bisa dilakukan dengan memodifikasi tingkah laku dan mengelola kelompok. Namun, yang juga perlu diperhatikan adalah menghindari hal-hal sebagai berikut, seperti campur tangan yang berlebihan, 
kesenyapan yang mengganggu proses pembelajaran, ketidaktepatan memulai dan mengakhiri kegiatan, penyimpangan dari tujuan, bertele-tele, dan pengulangan penjelasan yang tidak perlu.

\section{Keterampilan mengajar kelompok kecil dan perseorangan}

Dalam keterampilan mengajar kelompok kecil dan perseorangan, beberapa yang harus diperhatikan, yaitu: (a) mengadakan pendekatan secara pribadi. Ini bisa dilakukan dengan menunjukkan kehangatan dan kepekaan terhadap kebutuhan siswa baik dalam kelompok kecil maupun perorangan, mendengarkan secara simpatik ide-ide yang dikemukakan siswa, memberikan respons positif terhadap buah fikiran siswa, dan membangun hubungan saling mempercayai. Selain itu, juga bisa dengan menunjukkan kesiapan untuk membantu siswa tanpa kecenderungan untuk mendominasi ataupun mengambil alih tugas siswa, menerima perasaan siswa dengan penuh pengertian dan keterbukaan, dan berusaha mengendalikan situasi; (b) Mengorganisasi kelompok yang dilakukan dengan cara memberikan dan menjelaskan tugas atau masalah yang akan dipecahkan sebelum siswa atau kelompok mengerjakan kegiatan, memvariasikan kegiatan, membentuk kelompok yang tepat, mengkoordinasikan kegiatan, membagi-bagikan perhatian, dan mengakhiri kegiatan. Selanjutnya, (c) membimbing dan memudahkan pelajaran. Ini bisa dilakukan dengan cara memberikan penguatan yang sesuai, dan melakukan supervisi untuk memastikan segalanya berjalan dengan baik. Terakhir, (d) merencanakan dan melaksanakan kegiatan belajar mengajar dengan cara membantu siswa menetapkan tujuan pelajaran yang mencakup kriteria keberhasilan, langkahlangkah kerja, waktu serta kondisi belajar, merencanakan kegiatan belajar bersama siswa, bertindak atau berperan sebagai penasehat bagi siswa bila diperlukan, dan membantu siswa menilai pencapaian dan kemajuannya sendiri.

\section{Keterampilan memimpin diskusi kelompok kecil}

Keterampilan memimpin diskusi kelompok kecil bisa dilakukan dengan cara (a) memusatkan perhatian siswa pada tujuan atau topik diskusi; (b) memperjelas masalah urunan pendapat; (c) menganalisis pandangan siswa; (d) meningkatkan urunan siswa; (e) menyebarkan kesempatan berpartisipasi; dan (f) menutup diskusi. Tahap pertama adalah memusatkan perhatian siswa pada tujuan atau topik diskusi. Ini bisa dilakukan dengan cara mengenalkan topik dan mermuskan tujuan diskusi, mengemukakan masalah, mengembalikan diskusi ke arah semula bila terdapat penyimpangan dari pokok masalah yang sedang dibicarakan, dan merangkum hasil pembicaraan pada tahap-tahap tertentu sebelum melanjutkan dengan masalah berikutnya dengan memanfaatkan gagasan siswa. Contoh memanfaatkan gagasan siswa, misalnya, mengakui gagasan siswa dengan jalan mengulang bagian penting yang diucapkan, memodifikasi gagasan tersebut dengan cara menguraikannya, menggunakan gagasan siswa untuk mencapai kesimpulan, membandingkan gagasan siswa dengan gagasan yang telah diucapkan sebelumnya, dan merangkum hal-hal yang telah diuraikan siswa baik secara perorangan maupun kelompok.

Tahap selanjutnya adalah memperjelas masalah urunan pendapat. Ini dapat dilakukan dengan cara merangkum kembali permasalahan supaya jelas, meminta komentar siswa dengan mengajukan pertanyaan untuk memperjelas dan mengembangkan ide, dan menguraikan gagasan siswa dengan memberikan informasi tambahan atau contoh yang sesuai. Kemudian, dalam menganalisis pandangan siswa dapat dilakukan dengan cara meneliti apakah alasan tersebut memang mempunyai 
dasar yang kuat, memperjelas hal-hal yang disepakati dan tidak disepakati. Selain itu, perlu juga meningkatkan urunan siswa dengan cara mengajukan pertanyaan kunci yang menantang siswa untuk berfikir, memberikan contoh baik verbal maupun nonverbal yang sesuai pada saat yang tepat, menghangatkan suasana dengan mengajukan pertanyaan yang mengundang perbedaan pendapat, memberi dukungan kepada urunan siswa dengan jalan mendengarkan dengan penuh perhatian dan memberikan komentar yang positif atau mimik yang memberikan dorongan serta sikap yang bersahabat, dan memberi waktu yang cukup untuk berfikir tanpa diganggu dengan komentar guru.

Terakhir, menyebarkan kesempatan berpartisipasi dan menutup diskusi. Menyebarkan kesempatan berpartisipasi dapat dilakukan dengan cara menstimulus siswa untuk berfikir dan mengemukakan pendapat, memberikan kesempatan kepada yang belum bicara, mengatur jalannya diskusi, dan mengomentari pendapat yang dikemukakan bila diperlukan. Sementara itu, dalam menutup diskusi bisa dilakukan dengan cara membuat rangkuman hasil diskusi, menindaklanjuti hasil diskusi, dan menilai hasil diskusi.

\section{Metode Penelitian}

Penelitian ini menggunakan metode campuran (mixed method), yaitu suatu metode penelitian yang memadukan pendekatan kualitatif dan kuantitatif dalam semua tahapan proses penelitian (Sugiyono, 2013). Peneliti menggunakan metode gabungan dalam bentuk konkuren dengan model strategi embedded konkuren, yaitu strategi yang menggabungkan penelitian kuantitatif dan kualitatif dengan cara mengindukkannya. Pada penelitian ini, strategi yang digunakan peneliti adalah, penelitian kualitatif menginduk di dalam penelitian kuantitatif. Penelitian kuantitatif di sini didapatkan dari perhitungan hasil observasi data yang diperoleh peneliti, sedangkan penelitian kualitatif berdasarkan pendeskripsian hasil penelitian dalam bentuk verbal yang berwujud tulisan. Jadi, dari kedua data tersebut akan didapatkan integrasi temuan berupa deskripsi atau gambaran fakta dari objek yang diteliti, yaitu mendeskripsikan kemampuan mahasiswa Program Studi Pendidikan Bahasa Arab (Prodi PBA) Universitas Negeri Jakarta (UNJ) angkatan 2016 dalam menerapkan 8 keterampilan dasar mengajar guru dalam pembelajaran Pembinaan Kompetensi Mengajar (PKM).

\section{Hasil Penelitian}

\section{A. Respon Mahasiswa terhadap Mata Kuliah Pembinaan Kompetensi Mengajar}

Peneliti melakukan survey terhadap 80 orang mahasiswa Program Studi Pendidikan Bahasa Arab (Prodi PBA) Universitas Negeri Jakarta (UNJ) yang mengambil mata kuliah "Pembinaan Kompetensi Mengajar” (PKM) semester 110. Berikut adalah hasil survey yang dilakukan. 93\% mahasiswa Prodi PBA UNJ menyatakan memahami materi yang disampaikan pada mata kuliah PKM, sedangkan 7\% menyatakan ragu-ragu. Berkaitan dengan kesiapan melakukan praktik mengajar di sekolah, 80,2\% mahasiswa menyatakan siap dan 19,8\% menyatakan ragu-ragu. Selain itu, 98,8\% mahasiswa menyatakan bahwa menyaksikan rekan sejawat mereka melakukan praktik mengajar dapat memberikan manfaat bagi mereka, sedangkan 1,2\% menyatakan ragu-ragu. 83,7\% mahasiswa menyatakan memahami metode pembelajaran interaktif, $15,1 \%$ menyatakan ragu-ragu, dan 1,2\% menyatakan tidak memahami metode tersebut. 


\section{B. Keterampilan Dasar Mengajar Mahasiswa}

Persentase nilai rata-rata tertinggi hingga terendah dalam keterampilan mengajar dasar yang dikuasai mahasiswa Prodi PBA UNJ pada ujian praktik mengajar adalah sebagai berikut, keterampilan mengajar kelompok kecil dan perorangan dengan nilai 89,42\% dengan kategori sangat baik, dan keterampilan memberikan penguatan dengan nilai 85,00\% dengan kategori cukup.

\section{Keterampilan membuka dan menutup pelajaran}

Keterampilan pertama dari keterampilan dasar mengajar adalah keterampilan membuka dan menutup pelajaran. Keterampilan ini memiliki enam indikator, yaitu: (a) memfokuskan perhatian dan membangkitkan minat siswa; (b) menimbulkan motivasi; (c) memberi acuan; (d) mengaitkan pelajaran yang telah dipelajari dengan topik baru; (e) meninjau kembali; dan (f) mengevaluasi.

Tabel 1. Keterampilan membuka dan menutup pelajaran

\begin{tabular}{|c|c|c|c|c|}
\hline \multirow{2}{*}{ Indikator } & \multicolumn{2}{|c|}{ Observer 1} & \multicolumn{2}{|c|}{ Observer 2} \\
\hline & $\%$ & Kategori & $\%$ & Kategori \\
\hline $\begin{array}{l}\text { Memfokuskan perhatian dan } \\
\text { membangkitkan minat siswa }\end{array}$ & $84,44 \%$ & bagus & $84,47 \%$ & bagus \\
\hline Menimbulkan motivasi & $82,96 \%$ & bagus & $83,33 \%$ & bagus \\
\hline Memberi acuan & $85,93 \%$ & $\begin{array}{l}\text { sangat } \\
\text { bagus }\end{array}$ & $85,61 \%$ & bagus \\
\hline $\begin{array}{l}\text { Mengaitkan pelajaran yang telah } \\
\text { dipelajari dengan topik baru }\end{array}$ & $92,22 \%$ & $\begin{array}{l}\text { sangat } \\
\text { bagus }\end{array}$ & $92,05 \%$ & $\begin{array}{l}\text { sangat } \\
\text { bagus }\end{array}$ \\
\hline Meninjau kembali & $90,00 \%$ & $\begin{array}{l}\text { sangat } \\
\text { bagus }\end{array}$ & $89,78 \%$ & $\begin{array}{l}\text { sangat } \\
\text { bagus }\end{array}$ \\
\hline Mengevaluasi & $90,56 \%$ & $\begin{array}{l}\text { sangat } \\
\text { bagus }\end{array}$ & $90,35 \%$ & $\begin{array}{l}\text { sangat } \\
\text { bagus }\end{array}$ \\
\hline Rata-rata & \multicolumn{2}{|c|}{$87,69 \%$} & \multicolumn{2}{|c|}{$87,60 \%$} \\
\hline Rata-rata Keseluruhan & \multicolumn{4}{|c|}{$83,93 \%$} \\
\hline
\end{tabular}

2. Keterampilan bertanya

Keterampilan bertanya memiliki dua indikator, yaitu bertanya dasar dan bertanya lanjut.

Tabel 2. Keterampilan bertanya

\begin{tabular}{lcccc}
\hline \multirow{2}{*}{ Indikator } & \multicolumn{2}{c}{ Observer 1 } & \multicolumn{2}{c}{ Observer 2 } \\
\cline { 2 - 5 } & $\%$ & Kategori & $\%$ & Kategori \\
\hline \multirow{2}{*}{ Bertanya dasar } & $90,44 \%$ & sangat & $90,23 \%$ & sangat \\
Menimbulkan motivasi & $77,78 \%$ & bagus & $77,28 \%$ & bagus \\
Rata-rata & \multicolumn{3}{c}{$84,11 \%$} & \multicolumn{2}{c}{$83,76 \%$} \\
\hline \multicolumn{1}{c}{ Rata-rata Keseluruhan } & \multicolumn{3}{c}{$83,93 \%$} \\
\hline
\end{tabular}

3. Keterampilan mengadakan variasi

Keterampilan ketiga ini memiliki indikator yaitu mengadakan variasi dalam gaya belajar, varasi dalam penggunaan media dan variasi dalam pola interaksi dan aktivitas siswa. Variasi dalam gaya 
belajar yang dimaksud adalah penggunaan model-model pembelajaran yang digunakan dalam praktik mengajar bahasa Arab di kelas. Pengetahuan mahasiswa mengenai variasi gaya belajar didukung dengan mata kuliah yang telah mereka pelajari sebelumnya yaitu mata kuliah perencanaan dalam pembelajaran bahasa Arab. Selain itu, sebelum melakukan tugas praktik mengajar, mahasiswa diberikan pendalaman materi mengenai model-model pembelajaran efektif yang sesuai dengan pembelajaran bahasa Arab. Oleh karena itu, mahasiswa memiliki pemahaman yang memadai untuk melakukan variasi dalam gaya mengajar.

Tabel 3. Keterampilan mengadakan variasi

\begin{tabular}{|c|c|c|c|c|}
\hline \multirow{2}{*}{ Indikator } & \multicolumn{2}{|c|}{ Observer 1} & \multicolumn{2}{|c|}{ Observer 2} \\
\hline & $\%$ & Kategori & $\%$ & Kategori \\
\hline Variasi dalam gaya belajar & $96,67 \%$ & $\begin{array}{l}\text { sangat } \\
\text { bagus }\end{array}$ & $96,59 \%$ & $\begin{array}{l}\text { sangat } \\
\text { bagus }\end{array}$ \\
\hline Variasi dalam penggunaan media & $81,11 \%$ & bagus & $80,69 \%$ & bagus \\
\hline Variasi pola interaksi dan aktivitas mahasiswa & $77,78 \%$ & bagus & $77,28 \%$ & bagus \\
\hline Rata-rata & \multicolumn{2}{|c|}{$85,2 \%$} & \multicolumn{2}{|c|}{$84,86 \%$} \\
\hline Rata-rata Keseluruhan & \multicolumn{4}{|c|}{$85,0 \%$} \\
\hline
\end{tabular}

\section{Keterampilan mengelola kelas}

Indikator keterampilan mengelola kelas terdiri dari penciptaan dan pemeliharaan kondisi belajar yang optimal, pengendalian kondisi belajar yang optimal, dan menghindari hal-hal yang tidak berkaitan dengan pembelajaran. Pengelolaan kelas merupakan keterampilan yang dibutuhkan mahasiswa untuk menghadapi proses mengajar di sekolah. Meskipun, keadaan kelas saat mahasiswa melakukan ujian praktik dan keadaan kelas yang nyata tidak sepenuhnya sama, Namun, hal tersebut dapat memberikan gambaran kepada mahasiswa untuk menyiapkan diri mereka dalam menghadapi permasalahan yang mungkin dapat muncul di kelas selama proses belajar mengajar berlangsung.

Tabel 4. Keterampilan mengelola kelas

\begin{tabular}{lcccc}
\hline \multirow{2}{*}{ Indikator } & \multicolumn{2}{c}{ Observer 1 } & \multicolumn{2}{c}{ Observer 2 } \\
\cline { 2 - 5 } & $\%$ & Kategori & $\%$ & Kategori \\
\hline $\begin{array}{l}\text { Penciptaan dan pemeliharaan kondisi belajar } \\
\text { yang optimal }\end{array}$ & $88,22 \%$ & $\begin{array}{c}\text { sangat } \\
\text { bagus }\end{array}$ & $88,18 \%$ & $\begin{array}{c}\text { sangat } \\
\text { bagus }\end{array}$ \\
$\begin{array}{l}\text { Pengendalian kondisi belajar yang optimal } \\
\text { Menghindari hal-hal yang tidak berkaitan }\end{array}$ & $67,78 \%$ & cukup & $68,71 \%$ & cukup \\
$\begin{array}{l}\text { dengan pembelajaran } \\
\text { Rata-rata }\end{array}$ & $84,44 \%$ & bagus & $84,10 \%$ & bagus \\
\hline \multicolumn{1}{c}{ Rata-rata Keseluruhan } & $80,15 \%$ & & $80,15 \%$ \\
\hline
\end{tabular}

5. Keterampilan mengajar kelompok kecil dan perseorangan

Indikator keterampilan mengajar kelompok kecil dan perseorangan antara lain mengadakan pendekatan secara pribadi, mengorganisasi, membimbing dan memudahkan pelajaran, serta merencanakan dan melaksanakan kegiatan belajar mengajar. 
Tabel 5. Keterampilan mengajar kelompok kecil dan perseorangan

\begin{tabular}{lcccc}
\hline \multirow{2}{*}{ Indikator } & \multicolumn{2}{c}{ Observer 1 } & \multicolumn{2}{c}{ Observer 2 } \\
\cline { 2 - 5 } & $\%$ & Kategori & $\%$ & Kategori \\
\hline Mengadakan pendekatan secara pribadi & $99,37 \%$ & $\begin{array}{c}\text { sangat } \\
\text { bagus }\end{array}$ & $99,35 \%$ & $\begin{array}{c}\text { sangat } \\
\text { bagus }\end{array}$ \\
Mengorganisasi & & sangat & $95,08 \%$ & $\begin{array}{c}\text { sangat } \\
\text { bagus }\end{array}$ \\
Membimbing dan memudahkan pelajaran & $75,56 \%$ & cukup & $75,01 \%$ & cukup \\
Merencanakan dan melaksanakan kegiatan & $87,78 \%$ & bagus & $88,06 \%$ & bagus \\
belajar mengajar & \multicolumn{2}{c}{$89,47 \%$} & \multicolumn{2}{c}{$89,38 \%$} \\
Rata-rata & \multicolumn{3}{c}{$89,42 \%$} \\
\hline \multicolumn{7}{c}{ Rata-rata Keseluruhan }
\end{tabular}

6. Keterampilan memimpin diskusi kelompok kecil

Indikator keterampilan memimpin diskusi kelompok kecil antara lain dengan memusatkan perhatian siswa pada tujuan atau topik diskusi, memperjelas masalah urunan pendapat, menganalisis pandangan siswa, meningkatkan urunan siswa, menyebarkan kesempatan berpartisipasi, dan menutup diskusi.

Tabel 6. Keterampilan memimpin diskusi kelompok kecil

\begin{tabular}{|c|c|c|c|c|}
\hline \multirow{2}{*}{ Indikator } & \multicolumn{2}{|c|}{ Observer 1} & \multicolumn{2}{|c|}{ Observer 2} \\
\hline & $\%$ & Kategori & $\%$ & Kategori \\
\hline $\begin{array}{l}\text { Memusatkan perhatian siswa pada tujuan atau topik } \\
\text { diskusi }\end{array}$ & $91,67 \%$ & $\begin{array}{l}\text { sangat } \\
\text { bagus }\end{array}$ & $91,48 \%$ & $\begin{array}{l}\text { sangat } \\
\text { bagus }\end{array}$ \\
\hline Memperjelas masalah urunan pendapat & $83,70 \%$ & bagus & $84,08 \%$ & bagus \\
\hline Menganalisis pandangan siswa & $73,33 \%$ & cukup & $72,74 \%$ & cukup \\
\hline Meningkatkan urunan siswa & $84,44 \%$ & bagus & $84,10 \%$ & bagus \\
\hline Menyebarkan kesempatan berpartisipasi & $91,67 \%$ & $\begin{array}{l}\text { sangat } \\
\text { bagus }\end{array}$ & $91,48 \%$ & $\begin{array}{l}\text { sangat } \\
\text { bagus }\end{array}$ \\
\hline Menutup diskusi & $87,41 \%$ & $\begin{array}{l}\text { sangat } \\
\text { bagus }\end{array}$ & $87,13 \%$ & $\begin{array}{l}\text { sangat } \\
\text { bagus }\end{array}$ \\
\hline Rata-rata & \multicolumn{2}{|c|}{$85,37 \%$} & \multicolumn{2}{|c|}{$85,17 \%$} \\
\hline Rata-rata Keseluruhan & \multicolumn{4}{|c|}{$85,27 \%$} \\
\hline
\end{tabular}

7. Keterampilan menjelaskan

Keterampilan menjelaskan memiliki indikator sebagai berikut, yaitu menggunakan bahasa secara baik dan benar, menggunakan bahasa yang jelas, suara terdengar ke seluruh penjuru kelas, volume suara bervariasi, menghindari kata-kata yang tidak perlu, menghindari penggunakan kata "mungkin" yang salah pemakaian, dan menjelaskan pengertian istilah asing dan baru secara tuntas. Selain itu penting juga untuk meneliti pemahaman siswa terhadap penjelasan guru, memberi contoh nyata uraian materi sesuai pengalaman siswa, memberikan penjelasan secara deduktif/induktif dan membuat generalisasi, menggunakan multimedia bila diperlukan, menggunakan bagan untuk menjelaskan hubungan dan hirarki, menerima umpan balik dari siswa, dan memberikan kesempatan pada siswa untuk memberikan contoh sesuai dengan pengalamannya masing-masing, serta memberikan penekanan pada hal penting. 
Tabel 7. Keterampilan menjelaskan

\begin{tabular}{|c|c|c|c|c|}
\hline \multirow{2}{*}{ Indikator } & \multicolumn{2}{|c|}{ Observer 1} & \multicolumn{2}{|c|}{ Observer 2} \\
\hline & $\%$ & Kategori & $\%$ & Kategori \\
\hline Menggunakan bahasa secara baik dan benar & $97,78 \%$ & $\begin{array}{l}\text { sangat } \\
\text { bagus }\end{array}$ & $97,73 \%$ & $\begin{array}{l}\text { sangat } \\
\text { bagus }\end{array}$ \\
\hline Menggunakan bahasa yang jelas & $95,56 \%$ & $\begin{array}{l}\text { sangat } \\
\text { bagus }\end{array}$ & $95,46 \%$ & $\begin{array}{l}\text { sangat } \\
\text { bagus }\end{array}$ \\
\hline Suara terdengar ke seluruh penjuru kelas & $97,78 \%$ & $\begin{array}{l}\text { sangat } \\
\text { bagus }\end{array}$ & $97,73 \%$ & $\begin{array}{l}\text { sangat } \\
\text { bagus }\end{array}$ \\
\hline Volume suara bervariasi & $91,11 \%$ & $\begin{array}{l}\text { sangat } \\
\text { bagus }\end{array}$ & $84,10 \%$ & $\begin{array}{l}\text { sangat } \\
\text { bagus }\end{array}$ \\
\hline Menghindari kata-kata yang tidak perlu & $71,11 \%$ & cukup & $72,69 \%$ & cukup \\
\hline $\begin{array}{l}\text { Menghindari penggunakan kata "mungkin” yang salah } \\
\text { pemakaian }\end{array}$ & $95,56 \%$ & $\begin{array}{l}\text { sangat } \\
\text { bagus }\end{array}$ & $95,46 \%$ & $\begin{array}{l}\text { sangat } \\
\text { bagus }\end{array}$ \\
\hline $\begin{array}{l}\text { Menjelaskan pengertian istilah asing dan baru secara } \\
\text { tuntas }\end{array}$ & $97,78 \%$ & $\begin{array}{l}\text { sangat } \\
\text { bagus }\end{array}$ & $97,73 \%$ & $\begin{array}{l}\text { sangat } \\
\text { bagus }\end{array}$ \\
\hline Meneliti pemahaman siswa terhadap penjelasan guru & $80,00 \%$ & bagus & $79,56 \%$ & bagus \\
\hline $\begin{array}{l}\text { Memberi contoh nyata uraian materi sesuai pengalaman } \\
\text { siswa }\end{array}$ & $82,22 \%$ & bagus & $81,83 \%$ & bagus \\
\hline $\begin{array}{l}\text { Memberikan penjelasan secara deduktif/induktif dan } \\
\text { membuat generalisasi }\end{array}$ & $77,78 \%$ & bagus & $79,51 \%$ & bagus \\
\hline Menggunakan multimedia bila diperlukan & $51,11 \%$ & $\begin{array}{l}\text { sangat } \\
\text { kurang }\end{array}$ & $52,25 \%$ & $\begin{array}{l}\text { sangat } \\
\text { kurang }\end{array}$ \\
\hline $\begin{array}{l}\text { Menggunakan bagan untuk menjelaskan hubungan dan } \\
\text { hirarki }\end{array}$ & $80,00 \%$ & bagus & $79,56 \%$ & bagus \\
\hline Menerima umpan balik dari siswa & $95,56 \%$ & $\begin{array}{l}\text { sangat } \\
\text { bagus }\end{array}$ & $97,68 \%$ & $\begin{array}{l}\text { sangat } \\
\text { bagus }\end{array}$ \\
\hline $\begin{array}{l}\text { Memberikan kesempatan pada siswa untuk memberikan } \\
\text { contoh sesuai dengan pengalamannya masing-masing }\end{array}$ & $80,00 \%$ & bagus & $79,56 \%$ & bagus \\
\hline Memberikan penekanan pada hal penting & $97,78 \%$ & $\begin{array}{l}\text { sangat } \\
\text { bagus }\end{array}$ & $97,73 \%$ & $\begin{array}{l}\text { sangat } \\
\text { bagus }\end{array}$ \\
\hline Rata-rata & \multicolumn{2}{|c|}{$86,07 \%$} & \multicolumn{2}{|c|}{$86,36 \%$} \\
\hline Rata-rata Keseluruhan & \multicolumn{4}{|c|}{$86,22 \%$} \\
\hline
\end{tabular}

8. Keterampilan memberikan penguatan

Memberikan penguatan dapat dilakukan dengan beberapa cara. Hal ini dapat diketahui dari indikator keterampilan memberikan penguatan yang terdiri dari: (a) guru memberikan penguatan secara verbal berupa kalimat menghargai, kata-kata "ya", "bagus", "tepat”, dan lain-lain; (b) guru memberikan penguatan secara gestur (gerak) dalam bentuk mimik, senyum, kerlingan mata, tepuk tangan, anggukan kepala, menaikkan jempol; (c) guru memberikan penguatan dengan mendekati siswa atau duduk dalam kelompok diskusinya untuk memberikan perhatian terhadap aktivitasnya; (d) guru memberikan penguatan dengan sentuhan, seperti menepuk-nepuk pundak siswa, menjabat tangan atau mengangkat tangan siswa; (e) guru memberikan penguatan dengan memberikan hadiah/tanda atau memberi komentar pada tugas tertulis; dan (f) guru memberikan 
pekerjaan yang menyenangkan, seperti siswa untuk membantu temannya atau memimpin suatu kegiatan.

Tabel 8. Keterampilan memberikan penguatan

\begin{tabular}{|c|c|c|c|c|}
\hline \multirow{2}{*}{ Indikator } & \multicolumn{2}{|c|}{ Observer 1} & \multicolumn{2}{|c|}{ Observer 2} \\
\hline & $\%$ & Kategori & $\%$ & Kategori \\
\hline $\begin{array}{l}\text { Guru memberikan penguatan secara verbal berupa } \\
\text { kalimat menghargai/kata-kata “ya”, "bagus”, "tepat”, } \\
\text { dan lain-lain }\end{array}$ & $100,00 \%$ & $\begin{array}{l}\text { sangat } \\
\text { bagus }\end{array}$ & $100,00 \%$ & $\begin{array}{l}\text { sangat } \\
\text { bagus }\end{array}$ \\
\hline $\begin{array}{l}\text { Guru memberikan penguatan secara gesture (gerak), } \\
\text { dalam bentuk mimik, senyum, kerlingan mata, } \\
\text { tepuk tangan, anggukan kepala, menaikkan jempol }\end{array}$ & $100,00 \%$ & $\begin{array}{l}\text { sangat } \\
\text { bagus }\end{array}$ & $100,00 \%$ & $\begin{array}{l}\text { sangat } \\
\text { bagus }\end{array}$ \\
\hline $\begin{array}{l}\text { Guru memberikan pnguatan dengan mendekati } \\
\text { siswa atau duduk dalam kelompok diskusinya untuk } \\
\text { memberikan perhatian terhadap aktivitasnya }\end{array}$ & $100,00 \%$ & $\begin{array}{l}\text { sangat } \\
\text { bagus }\end{array}$ & $100,00 \%$ & $\begin{array}{l}\text { sangat } \\
\text { bagus }\end{array}$ \\
\hline $\begin{array}{l}\text { Guru memberikan penguatan dengan sentuhan, } \\
\text { seperti menepuk-nepuk pundak siswa, menjabat } \\
\text { tangan atau mengangkat tangan siswa }\end{array}$ & $95,56 \%$ & $\begin{array}{l}\text { sangat } \\
\text { bagus }\end{array}$ & $95,46 \%$ & $\begin{array}{l}\text { sangat } \\
\text { bagus }\end{array}$ \\
\hline $\begin{array}{l}\text { Guru memberikan penguatan dengan memberikan } \\
\text { hadiah/tanda atau memberi komentar pada tugas } \\
\text { tertulis }\end{array}$ & $57,78 \%$ & kurang & $56,84 \%$ & kurang \\
\hline $\begin{array}{l}\text { guru memberikan pekerjaan yang menyenangkan, } \\
\text { seperti siswa untuk membantu temannya atau } \\
\text { memimpin suatu kegiatan }\end{array}$ & $75,56 \%$ & cukup & $75,01 \%$ & cukup \\
\hline Rata-rata & \multicolumn{2}{|c|}{$88,15 \%$} & \multicolumn{2}{|c|}{$87,88 \%$} \\
\hline Rata-rata Keseluruhan & \multicolumn{4}{|c|}{$88,02 \%$} \\
\hline
\end{tabular}

\section{Pembahasan}

Keterampilan dasar mengajar merupakan kemampuan khusus yang harus dimiliki seorang guru. Oleh karena itu, mahasiswa Program Studi Pendidikan Bahasa Arab (Prodi PBA) Universitas Negeri Jakarta (UNJ) diharapkan mampu menguasai keterampilan dasar mengajar tersebut untuk dapat menciptakan proses belajar mengajar bahasa Arab yang efektif. Penelitian ini mengungkapkan kemampuan mahasiswa Prodi PBA UNJ angkatan 2016 dalam mengaplikasikan keterampilan dasar mengajar pada mata kuliah Pembinaan Kompetensi Mengajar (PKM) pada semester 110. Berikut ini adalah analisis hasil penelitian tersebut.

Keterampilan pertama adalah keterampilan membuka dan menutup pelajaran. Keterampilan ini miliki peran penting dalam memberikan pengaruh kesuksesan proses belajar mengajar. Mahasiswa Prodi PBA UNJ angkatan 2016 melakukan kegiatan membuka dan menutup pelajaran dengan berdoa. Kegiatan berdoa dapat dipimpin oleh guru dan juga terkadang menugaskan kepada salah satu murid untuk memimpin doa. Selain itu, mengaitkan pelajaran sebelumnya dengan topik baru merupakan indikator yang paling banyak dilakukan oleh mahasiswa Prodi PBA UNJ angkatan 2016, yaitu sebanyak 92,22\%. Kegiatan tersebut penting dilakukan untuk memfokuskan perhatian dan membangkitkan minat siswa untuk mempelajari materi baru yang akan disampaikan oleh guru. Mahasiswa Prodi PBA UNJ angkatan 2016 juga memberikan beberapa stimulus untuk memimbulkan motivasi siswa seperti dengan memberikan games, video motivasi, dan lainnya. Begitu 
pula dalam kegitan menutup pelajaran, hal terpenting yang dilakukan oleh mahasiswa Prodi PBA UNJ angkatan 2016 adalah melakukan evalusi pembelajaran dan meninjau kembali materi yang telah diajarkan. Evaluasi pembelajaran dapat dilakukan dengan memberikan pertanyaan-pertanyaan yang diberikan dalam bentuk permainan atau perlombaan kelompok.

Keterampilan menjelaskan merupakan keterampilan utama yang perlu diperhatikan oleh calon guru. Mahasiswa Prodi PBA UNJ angkatan 2016 memiliki tantangan tersediri karena materi yang akan mereka ajarkan adalah bahasa Arab. Selain beberapa indikator dalam keterampilan menjelaskan yang harus dikuasai oleh mereka, mahasiswa Prodi PBA UNJ angkatan 2016 juga harus menguasai materi bahasa Arab dasar pada SMP atau MTs dan SMA atau MA.

Keterampilan bertanya merupakan keterampilan yang memiliki hubungan dengan keterampilan menjelaskan. Pada keterampilan bertanya, guru diharapkan mampu menguasai komponen-komponen keterampilan bertanya dasar dan keterampilan bertanya lanjut. Keterampilan bertanya dasar merupakan keterampilan yang lebih banyak ditemukan dalam praktik mengajar mahasiswa Prodi PBA UNJ angkatan 2016 dengan jumlah rata-rata 90,44\%. Keterampilan bertanya dasar ini meliputi keterampilan guru dalam mengungkapkan pertanyaan dalam bahasa yang jelas dan singkat, tidak menimbulkan tafsiran ganda, dan juga memberikan waktu bagi sisa untuk memikirkan jawaban dari pertanyaan yang diajukan oleh guru. Di antara komponen keterampilan bertanya dasar adalah keterampilan untuk menghargai siswa sebagai insan pribadi, yaitu dengan memberikan apresiasi yang pantas bagi siswa yang telah berusaha menjawab pertanyaan guru.

Keterampilan mengadakan variasi dengan jumlah presentase terbanyak adalah pada keterampilan variasi dalam gaya mengajar, yaitu sebesar 96,67\%. Berdasarkan indikator dalam variasi gaya mengajar, dapat diketahui bahwa mahasiswa Prodi PBA UNJ angkatan 2016 mampu menerapkan keterampilan mengadakan variasi dalam gaya mengajar seperti memberikan variasi dalam nada, volume dan kecepatan berbicara saat melakukan proses belajar mengajar, mampu memberikan ekspresi wajah dalam menyajikan penjelasan materi dan mampu memusatkan perhatian siswa dan memposisikan dirinya di dalam kelas sesuai kebutuhannya.

Keterampilan memberikan penguatan (reinforcement) dalam proses belajar mengajar memiliki peran penting untuk memberikan motivasi bagi siswa. Pemberian penguatan dapat dilakukan dengan cara verbal, yaitu melalui kata-kata penghargaan. Mahasiswa Prodi PBA UNJ angkatan 2016 dalam pembelajaran bahasa Arab menggunakan penguatan verbal dengan ungkapan "ahsantalabsanti", "mumtāz", dan lain sebagainya.

Keterampilan mengelola kelas mahasiswa Prodi PBA UNJ angkatan 2016 terlihat dari kemampuan mereka untuk mengondisikan kelas sehingga pembelajaran bahasa Arab dapat terlaksana dengan optimal. Hal tersebut dapat dilihat dari kegiatan memulai pembelajaran ketika semua siswa sudah duduk dengan siap dan rapih. Selain itu, mereka juga menunjukkan sikap tanggap yaitu dengan menghampiri siswa yang bertanya. Mereka juga mampu memberikan teguran secara bijaksana bagi siswa yang tidak memperhatikan pelajaran dengan baik. Begitu pula, mahasiswa Prodi PBA UNJ angkatan 2016 mampu menghindari kegiatan yang bertele-tele.

Keterampilan mengajar kelompok kecil dan perseorangan merupakan keterampilan yang perlu dikuasi oleh guru. Hal ini dikarenakan mayoritas model pembelajaran dalam konteks kurikulum 2013 menggunakan pendekatan kooperatif. Oleh karena itu, mahasiswa Prodi PBA UNJ angkatan 2016 dituntut untuk mampu menguasai keterampilan mengajar kelompok kecil dan perseorangan 
dengan memerhatikan beberapa indikator terkait dengan keterampilan tersebut. Keterampilan tersebut juga berkaitan dengan keterampilan memimpin diskusi kelompok kecil.

Berdasarkan hasil penilaian terhadap keterampilan mengajar yang dilakukan mahasiswa Prodi PBA UNJ angkatan 2016 tersebut dapat diketahui beberapa keterampilan yang menurut mereka merupakan keterampilan yang paling sulit dilakukan. Keterampilan tersebut adalah keterampilan mengelola kelas, keterampilan mengadakan variasi, keterampilan menjelaskan, dan keterampilan bertanya.

\section{Simpulan}

Keterampilan dasar mengajar merupakan keterampilan yang harus dikuasai oleh seorang calon guru. Keterampilan ini terdiri dari 8 keterampilan dasar yang meliputi (1) keterampilan membuka dan menutup pelajaran; (2) keterampilan menjelaskan pelajaran; (3) keterampilan bertanya; (4) keterampilan mengadakan variasi; (5) keterampilan memberikan penguatan; (6) keterampilan mengelola kelas; (7) keterampilan mengajar kelompok kecil dan perseorangan; dan (8) keterampilan memimpin diskusi kelompok kecil.

Persentase nilai rata-rata tertinggi hingga terendah dalam keterampilan mengajar dasar yang dikuasai mahasiswa Prodi PBA UNJ pada ujian, yaitu keterampilan mengajar kelompok kecil dan perorangan dengan nilai 89,42\% yang termasuk kategori sangat baik, dan keterampilan memberikan penguatan dengan nilai 85,00\% kategori cukup. Dengan adanya penelitian ini, peneliti mendapatkan pemahaman tentang keterampilan dasar mengajar sekaligus data terkait keterampilan mengajar di Prodi PBA UNJ. Selain itu, penelitian ini juga dapat digunakan sebagai pedoman bagi penelitipeneliti lainnya mengenai keterampilan dasar mengajar.

Berdasarkan jajak pendapat yang dilakukan kepada mahasiswa Prodi PBA UNJ angkatan 2016, dapat diketahui bahwa mayoritas mahasiswa Prodi PBA UNJ angkatan 2016 menyatakan bahwa mereka memiliki kesulitan dapat memahami dan mengaplikasikan keterampilan terkait dengan variasi dan menjelaskan pelajaran. Mereka menyatakan bahwa mengadakan variasi dalam proses pembelajaran memiliki peran penting untuk mendapatkan perhatian siswa. Namun, hal tersebut juga membutuhkan waktu yang lebih lama untuk mempersiapkannya. Selain itu, mata pelajaran bahasa Arab juga memiliki karakteristik yang khusus, sehingga hal tersebut menjadi tantangan bagi mahasiswa Prodi PBA UNJ angkatan 2016 untuk lebih dapat memahami cara untuk menjelaskan materi bahasa Arab tersebut.

Di sisi lain, penilitian ini merekomendasikan beberapa hal yang berkaitan dengan peningkatan kualitas keterampilan mengajar mahasiswa dan mata kuliah "Pembinaan Kompetensi Mengajar" (PKM) di Prodi PBA UNJ. Pertama, perlu adanya pemberian contoh langsung mengenai variasi dan metode pembelajaran bahasa Arab yang terbaru dan sesuai dengan kurikulum 2013. Kedua, perlu adanya pendalaman materi bahasa Arab. Hal ini berdasarkan temuan bahwa masih terdapat kesalahan dari mahasiswa Prodi PBA UNJ angkatan 2016 yang melakukan kesalahan dalam menyampaikan materi yang diajarkannya. Ketiga, perlu dikembangkan instrumen penilaian praktik mengajar yang lebih disesuaikan dengan kebutuhan Prodi PBA UNJ. 


\section{Daftar Rujukan}

Helmiati. (2013). Micro teaching: Melatib keterampilan dasar mengajar. Yogyakarta: Aswaja Pressindo.

Hermawan, A. (2011). Metodologi pembelajaran bahasa Arab. Bandung: Rosdakarya.

Husien, L. (2017). Profesi keguruan: Menjadi guru profesional. Yogyakarta: Pustaka Baru Press.

Mulyasa, E. (2011). Menjadi guru profesional. Bandung: PT Remaja Rosdakarya.

Purwati., D. (2017). Penguasaan delapan keterampilan dasar mengajar mabasiswa Pendidikan Kimia angkatan 2013 di Universitas Islam Negeri Walisongo Semarang (Skripsi, UIN Walisongo Semarang). Retrieved from http://eprints.walisongo.ac.id/7817/

Rosyidi, A. W. (2009). Media pembelajaran bahasa Arab. Malang: UIN Malang Press.

al-Rājihịi, A. (1995). 'Ilm al-lughah al-tațbìqì wa-ta lìm al-lughah al-'Arabìyah. Iskandarīyah: Dār al-Ma'rifah al-Jāmi'īyah.

Siswanto. 2010. Tingkat penguasaan keterampilan dasar mengajar mahasiswa Prodi Pendidikan Akuntansi, Fakultas Ilmu Sosial dan Ekonomi, Universitas Negeri Yogyakarta. Jurnal Pendidikan Akutansi Indonesia, 8(2), 41-51. doi:10.21831/jpai.v8i2.953

Wahab, M. A. (2015). Pembelajaran bahasa Arab di era Posmetode. Arabiyat: Jurnal Pendidikan Babasa Arab dan Kebahasaaraban, 2(1), 59-74. doi:10.15408/a.v2i1.1519

Wijarini, F., \& Ilma, S. (2017). The analysis of teacher candidates' teaching skill in Department of Biology Education, University of Borneo Tarakan, through pre-service teaching activities. Jurnal Pendidikan Biologi Indonesia, 3(2), 149-159. Retrieved from http://ejournal.umm.ac.id/index.php/jpbi/article/view/4311 